\title{
Malnutrition and food insecurity in child labourers in Sindh, Pakistan: a cross-sectional study
}

Meesha Iqbal, ${ }^{1}$ Zafar Fatmi, ${ }^{1}$ Kausar Khan, ${ }^{1}$ Yusra Jumani, ${ }^{2}$ Neelma Amjad ${ }^{1}$ and Asaad Nafees ${ }^{1}$

${ }^{1}$ Department of Community Health Sciences, Aga Khan University, Karachi, Pakistan. ${ }^{2}$ Dow University of Health Sciences, Karachi, Pakistan. (Correspondence to: Meesha Iqbal: meesha.iqbal@aku.edu; meesha_jazz@hotmail.com).

\begin{abstract}
Background: Child labour is common in low- and middle-income countries. Although child labour is widespread in Pakistan, no data are available on the health of child labourers.

Aims: This study aimed to assess the food security, food intake and nutritional status of child labourers aged 5-14 years working in lower Sindh, Pakistan.

Methods: Child labourers aged 5-14 years working in agriculture, manufacturing industry, hotels and restaurants, domestic work and migrant child labourers working in vegetable markets were recruited using a respondent-driven sampling technique. Sociodemographic and nutrition information was obtained by an interviewer questionnaire. The children's height and weight were measured to assess stunting (height-for-age z scores less than -2 ) and wasting (weightfor-height $\mathrm{z}$ scores less than -2).

Results: A total of 634 child labourers were included: 184 worked in agriculture, 120 in industry, 67 in hotels and restaurants, 63 in domestic work and 200 were migrant child labourers. Overall, $15.5 \%$ of the children were stunted and $30.0 \%$ were wasted. The prevalence of stunting was highest in children working in agriculture $(27.2 \%)$ and the prevalence of wasting was highest in migrant child workers (35.0\%). About half the children (51.1\%) were suffering from food insecurity. Food inadequacy was mainly in consumption of vegetables/potatoes ( $98 \%$ of the children had inadequate intake), legumes (97\%), fruits $(96 \%)$, meat/ poultry $(95 \%)$ and milk/dairy products $(82 \%)$.
\end{abstract}

Conclusion: The nutritional status and food insecurity of the child labourers of Pakistan are comparable with the general population, highlighting the grave situation of the country with regard to food security.

Keywords: child labour, nutritional status, food supply, Pakistan

Citation: Iqbal M; Fatmi Z; Khan K; Jumani Y; Amjad N; Nafees A. Malnutrition and food insecurity in child labourers in Sindh, Pakistan: a cross-sectional study. East Mediterr Health J. 2020;26(9):1087-1096. https://doi.org/10.26719/emhj.20.040

Received: 13/11/18; accepted: 16/06/19

Copyright (C) World Health Organization (WHO) 2020. Open Access. Some rights reserved. This work is available under the CC BY-NC-SA 3.0 IGO license https://creativecommons.org/licenses/by-nc-sa/3.o/igo

\section{Introduction}

The International Labour Organization (ILO) classifies child labour as "work that deprives children of their childhood, their potential and their dignity, and that is harmful to physical and mental development" (1). Globally, 152 million children (58\% boys, $42 \%$ girls) aged 5-17 years were involved in child labour in 2016 (2). Migration, which may follow natural or man-made disasters or national and international conflicts, is one of the important reasons why children work (3-5). Poverty, poor schooling systems and low literacy rates, and large family size are also important causes of child labour $(6,7)$. Child labourers are estimated to contribute up to $10-20 \%$ of the family income in some low- and middle-income countries (8).

Labour has a significant effect on the lives of the children, including on their lifestyle, health, education and future job prospects $(6,7)$. Adverse health effects of child labour include poor growth, malnutrition, skin diseases, musculoskeletal disorders, and behavioural and mental disorders which can lead to several chronic diseases $(9,10)$. The decreased food availability and variety, combined with occupational hazards, puts the physical health and nutritional status of child labourers at greater risk (11,12). We postulated a theoretical framework of child labour and malnutrition (Figure 1). Poverty leads to food insecurity forcing the children to start work at an early age. The harsh working environment offers less food and variety in food (they generally do not get meals at work) leading to food inadequacy and consequently malnutrition and the other effects outlined above.

Pakistan is the world's fifth most populous country with an estimated population of 208 million people (13). According to the latest ILO report, the global burden of child labour is declining; however, the number of children in child labour has steadily increased in Pakistan, from 3.3 million in 1996 to an estimated 12.5 million in 2012 $(14,15)$. In 2010-2011, many families migrated to the cities because of heavy floods that hit Pakistan. Migration is a push factor for child labour in the cities (16). Information on the health status of child labourers is scarce in Pakistan. Therefore, we conducted a survey in the cities of the lower part of Sindh province to assess nutrition in child labourers including: food availability, food intake and nutritional status. We included child labourers in the agricultural sector, manufacturing industry, hotel 
Figure 1 Child labour and malnutrition: a conceptual framework

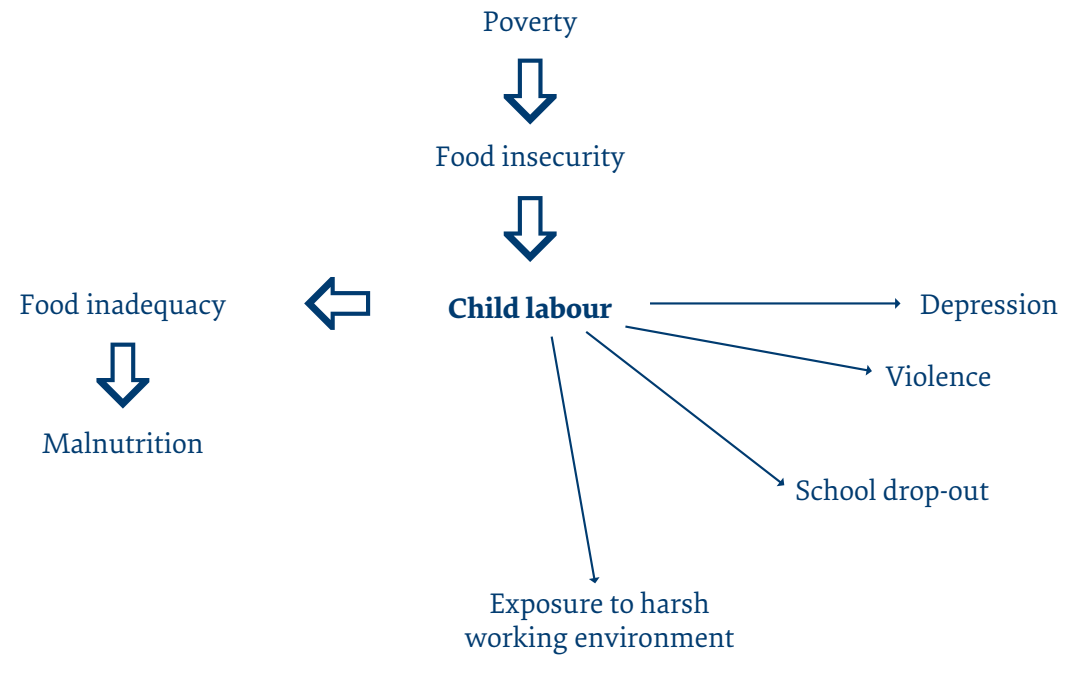

and restaurant sector, domestic work and migrants. The migrant children only worked in the vegetable market.

\section{Methods}

\section{Study design and setting}

This analysis is part of a larger mixed-methods study designed to assess the health and social status of the child labourers in suburban areas of lower Sindh (Karachi, Hyderabad and Thatta districts), Pakistan. The study was conducted from May to November 2017. We report the results of the cross-sectional survey to assess the physical health, nutritional status and food insecurity of the child labourers.

We included children aged between 5 and 14 years who had been working for at least 9 months in the past year. Fourteen is the minimum legal age for work in Pakistan. We considered any sort of work - formal or informal, paid or unpaid, casual or regular, full time or part time, seasonal or year round, legal or illegal - as labour as per ILO convention 138 (17).

The 1996 National Labour Survey of Pakistan identified that child labourers in Sindh were employed in: agricultural sector (46\%), manufacturing industry $(18 \%)$, hotels and restaurants $(16 \%)$, domestic work $(10 \%)$, transport sector $(8 \%)$, and construction sector $(2 \%)(14)$. We therefore drew our sample proportionately according to the above working groups. However, the transport and construction sectors were not included as their representation was too small in the overall sample.

Children working in hotels, restaurants and domestic work were sampled from Karachi. Children working in the agricultural sector of Karachi, Thatta and Hyderabad districts were selected based on feasibility and ease of access. It is hard to reach child labourers in Pakistan because of gangs. We had links in these areas and hence knew people who connected us to the children and their community. Children for the manufacturing group were sampled from bangle and handicraft industries of Hyderabad, which is well known for using child labourers, and from children working in warehouses and the fishery industry in the outskirts of Karachi.

We considered migration as a critical factor aggravating child labour; however, migrants were not considered in National Labour Survey of Pakistan. Migrants in Karachi form well defined communities. We selected migrant children from settlements along the socalled super highway (a road in Karachi), which are the largest migrant areas of the city.

\section{Sample size and sampling}

The sample size was calculated assuming a proportion of stunting in child labourers of $26 \%$, relative precision of $25 \%$ and $95 \%$ confidence level (18). The minimum sample needed was 318 children after increasing based on a 10\% refusal rate.

We used respondent-driven sampling, which is considered appropriate to sample hidden populations. Respondent-driven sampling is a form of snowball sampling but it is implemented in a way that uses mathematical modelling for the calculation of selection probabilities; thus qualifying as a probability sampling technique (19). Since the group of migrant children was clustered in certain areas of Karachi, the initial children were selected based on convenience sampling. They were given coupons and a monetary incentive to recruit other children working in the same group. Each recruited child was also given coupons and a monetary incentive to continue the chain until the sample size was reached.

\section{Data collection tool}

We used a structured interview questionnaire to assess the food security (adapted and modified from National Health Interview Survey, 2016) and nutritional intake (20) (Appendix 1, Appendix 2). The tool used had been previously validated in Pakistan and had also been used in the National Nutrition Survey of Pakistan. Interviews were conducted by the research team, including a research associate, a resident medical officer and a volunteer med- 
ical student. In addition, we measured the children's height and weight. Food security was defined as access by all people at all times to enough food for an active and healthy life $(20,21)$. The children were asked about their intake of the common food items in the past year (Appendix 1, Appendix 2), which was compared with the Malaysian dietary guidelines for children and adolescents for adequate and inadequate intake (22). National level guidelines are not available for Pakistan and we selected the Malaysian guidelines because Malaysians' eating habits are similar to Pakistani people.

\section{Statistical analysis}

WHO Anthro plus was used to calculate the z-scores for height-for-age (stunting) and weight-for-height (wasting) to assess the nutritional status of children. Children having $\mathrm{z}$-scores less than -2 were categorized as stunted (chronic malnutrition) or wasted (acute malnutrition). Proportions, frequencies and 95\% confidence intervals (CI) were calculated. The Pearson chi-squared test and one-way analysis of variance (ANOVA) were used to determine the differences between the occupational groups in stunting, wasting and food security. Six questions were asked about food availability and a positive answer for just one question was considered as food insecurity (see Annex 1). Data were analysed using SPSS, version 23 and Stata, version 8.

\section{Ethical considerations}

The Ethical Review Committee of the Aga Khan University approved the study. Consent was taken from the children before the interview.

\section{Results}

In total, 634 children were included in our study: 184 from the agricultural sector, 120 from the manufacturing industry, 67 from hotels and restaurants, 63 domestic workers and 200 migrant child labourers. Almost a quarter of the children 148 (23.3\%) were aged 5-9 years, while $486(76.7 \%)$ were 10 years or older. Table 1 shows the socioeconomic and demographic characteristics of the children. The mean age and standard deviation (SD) of the children ranged from 10.2 (SD 2.2) years in the migrant children to 11.9 (SD 1.7) years in the children working in the manufacturing industry. Of the children in our study, 322 (50.8\%) were boys: most of the children working in hotels and restaurants were boys (66, 98.5\%), whereas most of the children in domestic work were girls $(55,87.3 \%)$. The rest of the occupational groups had more equal gender distribution. Overall, the children worked for an average of 6.12 (SD 0.98) days a week and 6.81 (SD 3.09) hours a day. The children earned a mean of 4462.7 Pakistan rupees (Rs) a month (US $\$ 1=104.8$ Rs in 2017), with the migrant children earning the most (Rs 5688.5 a month, US\$ 54.3) and the agricultural workers the least (Rs 3077.3 a month, US\$29.4). A good proportion of children $(45.1 \%)$ said that they had previously attended the

\begin{tabular}{|c|c|c|c|c|c|c|}
\hline Characteristic & $\begin{array}{c}\text { Total } \\
(n=634)\end{array}$ & $\begin{array}{l}\text { Migrants } \\
(n=200)^{a}\end{array}$ & $\begin{array}{l}\text { Agriculture } \\
\quad(n=184)\end{array}$ & $\begin{array}{l}\text { Manufacturing } \\
\text { industry } \\
(n=120)\end{array}$ & $\begin{array}{l}\text { Hotels \& } \\
\text { restaurants } \\
(n=67)\end{array}$ & $\begin{array}{c}\text { Domestic } \\
\text { work } \\
(n=63)\end{array}$ \\
\hline Age (years), mean (SD) & $10.9(2.06)$ & $10.2(2.2)$ & $10.8(1.8)$ & $11.9(1.7)$ & $11.1(1.8)$ & $11.1(1.9)$ \\
\hline \multicolumn{7}{|l|}{ Sex, no. (\%) } \\
\hline Male & $322(50.8)$ & $127(63.5)$ & $74(40.2)$ & $47(39.2)$ & $66(98.5)$ & $8(12.7)$ \\
\hline Female & $312(49.2)$ & $73(36.5)$ & $110(59.8)$ & $73(60.8)$ & $1(1.5)$ & $55(87.3)$ \\
\hline Ethnicity, no. (\%) & $(n=434)$ & & $(n=173)$ & & & \\
\hline Sindhi & $225(51.8)$ & - & $161(93.1)$ & $29(24.2)$ & $17(25.4)$ & $18(28.6)$ \\
\hline Punjabi & $122(28.1)$ & - & $0(0.0)$ & $57(47.5)$ & $34(50.7)$ & $31(49.2)$ \\
\hline Other & $87(20.0)$ & - & $12(6.9)$ & $34(28.3)$ & $16(23.9)$ & $14(22.2)$ \\
\hline Income/month $(\mathrm{Rs})^{b}$, mean (SD) & $4462.7(3850.0)$ & $5688.5(4683.7)$ & $3077.3(2912.6)$ & $5045.3(4118.2)$ & $4240.9(2247.9)$ & $3338.1(2051.5)$ \\
\hline \multicolumn{7}{|l|}{ Type of house $e^{c}$, no. (\%) } \\
\hline Pakka & $153(24.1)$ & $3(1.5)$ & $10(5.4)$ & $75(62.5)$ & $27(40.3)$ & $38(60.3)$ \\
\hline Semi-pakka & $190(30.0)$ & $3(1.5)$ & $91(49.5)$ & $39(32.5)$ & $38(56.7)$ & $19(30.2)$ \\
\hline Kacha & $291(45.9)$ & $194(97.0)$ & $83(45.1)$ & $6(5.0)$ & $2(3.0)$ & $6(9.5)$ \\
\hline No. people living in house, mean (SD) & $8.28(3.49)$ & $9.1(3.3)$ & $7.5(2.4)$ & $8.5(4.7)$ & $7.9(3.6)$ & $7.6(3.1)$ \\
\hline Currently going to school, no. (\%) & $174(27.4)$ & $59(29.5)$ & $34(18.5)$ & $55(45.8)$ & $7(10.4)$ & $19(30.2)$ \\
\hline Ever attended school, no. (\%) & $286(45.1)$ & $95(47.5$ & $55(29.9)$ & $61(50.8)$ & $43(64.2)$ & $32(50.8)$ \\
\hline
\end{tabular}

SD: standard deviation.

${ }^{a}$ Migrant children worked in the vegetable markets.

${ }^{b}$ US $1=104.8$ Pakistani rupees (Rs).

'Pakka is a house built of cement; kacha is made of mud; and semi-pakka has straw, mud, wood and bamboos and sometimes a tin roof but no cement is used.

$\mathrm{P}<0.01$ for all the variables; Pearson chi-squared test and one-way ANOVA. 
school for at least a month, but only $27.4 \%$ were currently going to school.

Overall, 15.5\% (95\% CI: 12.9-18.5) were stunted (chronic malnutrition) and 30.0\% (95\% CI: 26.5-33.6) were wasted (acute malnutrition) (Figure 2). The highest prevalence of stunting was in children working in agriculture (27.2\%), and the lowest in the migrant child workers (9.0\%). The prevalence of wasting was highest in the migrant children (35.0\%) and lowest in children working in manufacturing (26.7\%) (Figure 2). Stunting was significantly more common in girls $(21 \%, 65 / 312)$ than boys $(9.6 \%, 31 / 322 ; P$ $<0.001)$.

The mean number of meals a day eaten by the children was of 2.76 (SD 0.5). Just over half ate homecooked food (55\%) and drank tap water (54.9\%). Most children working in the agricultural sector (53.8\%) drank water from a borehole. Food insecurity was seen in $51.1 \%$ of the children, and was highest in the domestic workers (60.3\%) and agricultural workers (59.8\%) (Table 2).

Table 3 shows that adequacy of daily food intakes according to different food groups and age groups. Most of the children had an inadequate daily intake of all the food groups (fruits, vegetables, legumes, milk/dairy products and meat/ poultry).

About $21.5 \%$ of the children had skipped food for at least one day in the previous month and $24.0 \%$ said they had lost weight because of being unable to afford food. We estimated a high intake of tea and sweets (chocolate, toffee and cotton candy) in the children with a mean of 1.55 cups (SD 1.02) of tea day and 0.91 (IQR: 0.86) sweets a day.

\section{Discussion}

Our study findings show that $30.0 \%$ and $15.5 \%$ of the child labourers suffered from acute and chronic malnutrition, respectively. Stunting was significantly more common in girls than boys. About half the children (51.1\%) were affected by food insecurity, and an alarming prevalence of food inadequacy was observed in the consumption of fruits, vegetables/potatoes, milk/dairy products, legume and meat/poultry. However, the estimates of malnutrition and food insecurity were no worse than the general population of Pakistan, which was $58 \%$ according to the national nutrition survey in $2011(23,24)$.

Few data are available on the nutritional status of child labourers in Pakistan. The Pakistan Demographic and Health Survey and the Multiple Indicator Cluster Survey (Sindh) offer nutritional estimates only for children under 5 years of age $(25,26)$. Thus, no national survey was available for comparison.

A study in Islamabad found that $20 \%$ and $12 \%$ of street children under 14 years were stunted and wasted respectively (27). Street children are generally thought to have a greater risk of poorer health and violence and a very vulnerable group. While they were not included in our study, the nutritional status of our child labourers was worse, highlighting the high susceptibility of working children to malnutrition. Our estimates also correspond to national estimates of the World Food Programme in 2017 where $18 \%$ of the population of Pakistan faced severe shortage of food (24). The culture and environment of Bangladesh is comparable to Pakistan and so are the estimates. A study in Dhaka, Bangladesh estimated that $15 \%$ and $26 \%$ of the child labourers in the city aged 5-17 years were wasted and stunted, respectively (18). Our estimates of acute malnutrition (30\% wasting) are similar to the estimates for child labourers working in

Figure 2 Nutritional status of the child labourers (5-14 years) in suburban areas of lower Sindh, by occupational group ( $n=634$ )

40

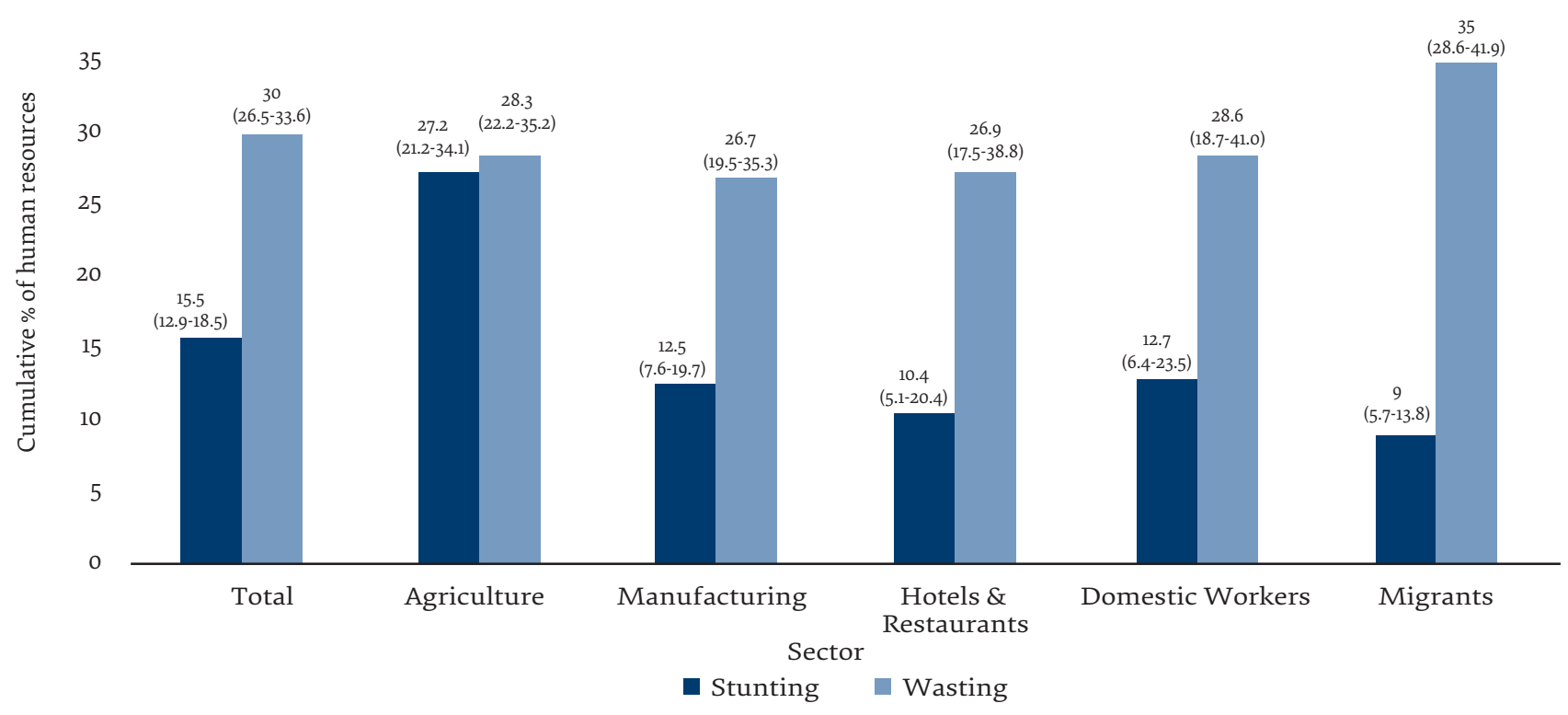




\begin{tabular}{|c|c|c|c|c|c|c|}
\hline Variable & $\begin{array}{c}\text { Total } \\
(n=634)\end{array}$ & $\begin{array}{l}\text { Migrants } \\
(n=200)\end{array}$ & $\begin{array}{l}\text { Agriculture } \\
(n=184)\end{array}$ & $\begin{array}{l}\text { Manufacturing } \\
\text { industry }(n=120)\end{array}$ & $\begin{array}{l}\text { Hotels \& } \\
\text { restaurants } \\
(n=67)\end{array}$ & $\begin{array}{c}\text { Domestic } \\
\text { work } \\
(n=63)\end{array}$ \\
\hline No. of meals/day, mean (SD) & $2.76(0.50)$ & $2.91(0.32)$ & $2.45(0.55)$ & $2.87(0.36)$ & $2.91(0.38)$ & $2.87(0.33)$ \\
\hline \multicolumn{7}{|l|}{ Source of food, no. (\%) } \\
\hline Home only & $349(55.0)$ & $108(54.0)$ & $101(54.9)$ & $98(81.7)$ & $7(10.4)$ & $35(55.6)$ \\
\hline Market/workplace and home & $184(29.0)$ & $84(42.0)$ & $9(4.9)$ & $10(8.3)$ & $59(88.1)$ & $22(34.9)$ \\
\hline Does not eat at work & $92(14.5)$ & $6(3.0)$ & $74(40.2)$ & $5(4.2)$ & $1(1.5)$ & $6(9.5)$ \\
\hline Other & $9(1.4)$ & $2(1.0)$ & $0(0.0)$ & $7(5.8)$ & $0(0.0)$ & $0(0.0)$ \\
\hline \multicolumn{7}{|l|}{ Food insecurity, no. (\%) } \\
\hline No & $310(48.9)$ & $106(53.0)$ & $74(40.2)$ & $69(57.5)$ & $36(53.7)$ & $25(39.7)$ \\
\hline Yes & $324(51.1)$ & $94(47.0)$ & $110(59.8)$ & $51(42.5)$ & $31(46.3)$ & $38(60.3)$ \\
\hline \multicolumn{7}{|c|}{ Source of drinking water at work, no. (\%) } \\
\hline Tap water/pipe water & $348(54.9)$ & $159(79.5)$ & $50(27.2)$ & $57(47.5)$ & $43(64.2)$ & $39(61.9)$ \\
\hline Borehole (hand pump/motor) & $142(22.4)$ & $11(5.5)$ & $99(53.8)$ & $31(25.8)$ & $0(0.0)$ & $1(1.6)$ \\
\hline Well/pond/river/stream & $39(6.2)$ & $7(3.5)$ & $32(17.4)$ & $0(0.0)$ & $0(0.0)$ & $0(0.0)$ \\
\hline Water filter (jerry can) & $59(9.3)$ & $2(1.0)$ & $1(0.5)$ & $27(22.5)$ & $6(9.0)$ & $23(36.5)$ \\
\hline Water tanker & $33(5.2)$ & $14(7.0)$ & $0(0.0)$ & $1(0.8)$ & $18(26.9)$ & $0(0.0)$ \\
\hline Don't know & $13(2.1)$ & $7(3.5)$ & $2(1.1)$ & $4(3.3)$ & $0(0.0)$ & $0(0.0)$ \\
\hline
\end{tabular}

SD: standard deviation.

$P<0.01$ for all the variables; Pearson chi-squared test.

Philippines, where $38.3 \%$ (mean age 14.3 years, SD: 2.0 ) suffered from wasting (28).

Our data show a high level of food insecurity (51.1\%) which is in line with the National Nutrition Survey of Pakistan 2011, which reported that $58 \%$ of households were food insecure (23). The World Food Programme also reported that $43 \%$ of the population was food insecure with $18 \%$ facing a severe shortage (24). A high proportion of the children had food inadequacy in all the food groups. The intake of bread, rice, grains was not asked about in our study; we assumed their intake was high as these are the cheapest available staple foods. A reasonable intake of wheat and bread among the working children aged 8-18 years was also reported in a study in the Islamic Republic of Iran (29).

Our results highlight the variation in the nutritional status of children working in the different occupational sectors. The highest prevalence of food insecurity was in children working in the agricultural sector $(60 \%)$ which reflected the higher prevalence chronic malnutrition $(27 \%)$ in these children. Although most of the children working in agriculture were working in the family business, they were at greater risk of food insecurity and deteriorating physical health compared with other groups. At the same time, $60 \%$ of children doing domestic work also had food insecurity but only $12.7 \%$ were stunted. The reasons for this difference in the prevalence of stunting with the same prevalence of food insecurity warrant investigation.

Interestingly, our estimates of food insecurity and nutritional status of the child labourers were not worse than the general population of Pakistan, although we thought they would be. This lack of difference is probably because many people in Pakistan are poor and hence cannot afford all the food they need. This might lead one to wonder if child labourers are better off compared with other children. We believe that the fact that the nutritional status of the child workers in our study was similar to the general population could also be attributed to the healthy worker effect; with more healthy children

Table 3 Adequacy of daily intake of different food groups of child labourers, by age group

\begin{tabular}{|c|c|c|}
\hline \multirow[t]{3}{*}{ Food group } & \multicolumn{2}{|c|}{ Age (years) } \\
\hline & $5-9(n=148)$ & $\geq 10(n=486)$ \\
\hline & No. (\%) & No. (\%) \\
\hline \multicolumn{3}{|l|}{ Fruit } \\
\hline Adequate & $2(1.4)$ & $18(3.7)$ \\
\hline Inadequate & $146(98.6)$ & $468(96.3)$ \\
\hline \multicolumn{3}{|l|}{ Vegetables/potatoes } \\
\hline Adequate & $6(4.1)$ & $7(1.4)$ \\
\hline Inadequate & $142(95.9)$ & 479 (98.6) \\
\hline \multicolumn{3}{|l|}{ Legumes } \\
\hline Adequate & $38(25.7)$ & $87(17.9)$ \\
\hline Inadequate & $110(74.3)$ & $399(82.1)$ \\
\hline \multicolumn{3}{|l|}{ Milk/dairy products } \\
\hline Adequate & $4(2.7)$ & $13(2.7)$ \\
\hline Inadequate & $144(97.3)$ & $473(97.3)$ \\
\hline \multicolumn{3}{|l|}{ Meat/poultry } \\
\hline Adequate & $38(25.7)$ & $24(4.9)$ \\
\hline Inadequate & $110(74.3)$ & $462(95.1)$ \\
\hline
\end{tabular}

The mean intake was compared with the Malaysian dietary guidelines for children and adolescents (22). The guidelines are different for 5-9 year olds and those $\geq 10$ years. 
being selected for work and being able to continue to work. This could also be the reason of higher proportions of acute compared to chronic malnutrition in this group. The effect of work on the health of these children over time has is yet to be studied and we believe that they might be at risk of deteriorating health in future due to inadequate availability of food. In addition, there is a need to evaluate if previous interventions to help alleviate the situation of child labour in Pakistan have been effective.

To the best of our knowledge, this is the first study to assess the nutritional status of child labourers in different occupational sectors in Pakistan. One of the major strengths of our study was its sampling technique as respondent-driven sampling is considered a good strategy to sample hidden populations (30). Migrants, who are generally neglected and not included among child labourers, were also included in our study. Moreover, the sample size was sufficient and validated tools followed by robust analysis were used to assess the outcomes. However, our study has some limitations.
Although respondent-driven sampling is the accepted technique to sample the hidden populations, some of the children in our study might not have been labourers and were brought by other children because of the monetary incentive. Furthermore, our sample did not have sufficient power to detect statistically significant differences between the working groups. The National Labour Survey of Pakistan does not consider children working on the streets, in carpet industries or cottage industries in the estimated cohort so they were not included in our study. However, we believe that these are important groups of child labour missed in our study. Our study did not capture data of children who left work because of disability, illness or death. Lastly, we also cannot eliminate the possibility of recall bias and reporting bias while interviewing the participants.

Further studies are needed to evaluate child labour and nutrition and to develop strategies and policies to tackle child labour and associated health and well-being problems.

\section{Acknowledgement}

We thank our research team and the children who took time to participate in our study.

Funding: World Health Organization, Regional Office for the Eastern Mediterranean: Research in priority areas of public health grant scheme, 2016-2017 (RPPH 16-104).

Competing interests: None declared. 


\section{Appendix 1: Questionnaire to assess the food and water intake.}

Ask the child if he/she eats the following. If the child says yes then ask him/her how many times a week he ate the following in the past 30 days.

\begin{tabular}{|c|c|c|c|c|c|c|c|c|c|}
\hline & & $\mathbf{0}$ & 1 & 2 & 3 & 4 & 5 & 6 & 7 \\
\hline 1 & $\begin{array}{l}\text { Do you eat daal/chole/lobia? } \\
\text { (any beans or lentils) }\end{array}$ & & & & & & & & \\
\hline 2 & $\begin{array}{l}\text { Do you eat vegetables? } \\
\text { (Cooked or raw vegetables, except potatoes) }\end{array}$ & & & & & & & & \\
\hline 3 & $\begin{array}{l}\text { Do you eat potatoes? } \\
\text { (Cooked/fried/any form) }\end{array}$ & & & & & & & & \\
\hline 4 & Do you eat fruits? & & & & & & & & \\
\hline 5 & Do you eat eggs? & & & & & & & & \\
\hline 6 & $\begin{array}{l}\text { Do you eat meat/chicken/fish? } \\
\text { (Beef/mutton any animal meat) }\end{array}$ & & & & & & & & \\
\hline 7 & $\begin{array}{l}\text { Do you take Milk/Yogurt/Lassi/Cheese? } \\
\text { (Any form of milk) }\end{array}$ & & & & & & & & \\
\hline 8 & Do you eat butter/ghee/cream (balai)? & & & & & & & & \\
\hline 9 & Do you drink tea? & & & & & & & & \\
\hline 10 & Do you eat packed chips/slanty? & & & & & & & & \\
\hline 11 & Do you eat toffees/chocolates/cotton candy? & & & & & & & & \\
\hline 12 & $\begin{array}{l}\text { Do you eat peanuts/almonds/seeds? } \\
\text { (any seeds like watermelon/sunflower seeds or dry fruit) }\end{array}$ & & & & & & & & \\
\hline 13 & $\begin{array}{l}\text { What is your main source of drinking water during working } \\
\text { hours? }\end{array}$ & \multicolumn{8}{|c|}{$\begin{array}{l}\text { 1. Tap water/pipe water } \\
\text { 2. Boring (hand pump/motor) } \\
\text { 3. Well } \\
\text { 4. Pond/river/stream } \\
\text { 5. Refused } \\
\text { 6. Don't know } \\
\text { 7. Others }\end{array}$} \\
\hline 14 & $\begin{array}{l}\text { What is your main source of drinking water after working } \\
\text { hours? }\end{array}$ & \multicolumn{8}{|c|}{$\begin{array}{l}\text { 8. Tap water/pipe water } \\
\text { 9. Boring(h and pump/motor) } \\
\text { 10. Well } \\
\text { 11. Pond/river/stream } \\
\text { 12. Refused } \\
\text { 13. Don't know } \\
\text { 14. Others }\end{array}$} \\
\hline 15 & Do you purify water before drinking? & \multicolumn{8}{|c|}{$\begin{array}{l}\text { 15. Yes } \\
\text { 16. No }\end{array}$} \\
\hline
\end{tabular}

\section{Appendix 2}

Q1: In the last 30 days, did you ever skip meals because there wasn't enough money for food?

Q2: In the last 30 days, how many days did this happen? *

Q3: In the last 30 days, did you ever eat less than you felt you should because there wasn't enough money for food?

Q4: In the last 30 days, did you lose weight because there wasn't enough money for food?

Q5: In the last 30 days, did you ever not eat for a whole day because there wasn't enough money for food?

Q6: In the last 30 days, how many days did this happen? *

*Greater or equal to 3 days was considered "yes"

A single "yes" answer was considered as "food insecurity" 


\section{Étude transversale de la malnutrition et de l'insécurité alimentaire chez les enfants travailleurs du Sindh (Pakistan)}

\section{Résumé}

Contexte : Le travail des enfants est courant dans les pays à revenu faible et intermédiaire. Bien que le travail des enfants soit répandu au Pakistan, aucune donnée n'est disponible sur la santé des enfants travailleurs.

Objectifs : La présente étude avait pour objectif d'évaluer la sécurité alimentaire, les apports alimentaires et l'état nutritionnel d'enfants âgés de 5 à 14 ans et travaillant dans le bas Sindh (Pakistan).

Méthodes : Des enfants âgés de 5 à 14 ans travaillant dans les secteurs de l'agriculture, de l'industrie de transformation, des hôtels et restaurants et du travail domestique, ainsi que des enfants de migrants travaillant sur les marchés de légumes, ont été recrutés au moyen de la méthode d'échantillonnage déterminé selon les répondants. Des informations sociodémographiques et nutritionnelles ont été recueillies à l'aide d'un questionnaire d'entretien. La taille et le poids des enfants ont été mesurés enfin d'évaluer le retard de croissance (score z de la taille-pour-l'âge inférieur à -2) et l'émaciation (score $z$ du poids-pour-l'âge inférieur à -2).

Résultats : Au total, 634 enfants travailleurs ont été inclus dans l'étude : 184 travaillaient dans l'agriculture, 120 dans l'industrie, 67 dans des hôtels et restaurants et 63 dans le travail domestique; 200 étaient des enfants de migrants. Dans l'ensemble, un retard de croissance a été observé chez 15,5\% des enfants et une émaciation chez 30,0 \% d'entre eux. La prévalence du retard de croissance était plus élevée chez les enfants travaillant dans l'agriculture (27,2\%), tandis que la prévalence de l'émaciation était plus élev ée chez les enfants de migrants (35,0\%). Près de la moitié des enfants (51,1\%) souffraient d'insécurité alimentaire. Les insuffisances alimentaires constatées concernaient principalement la consommation de légumes et de pommes de terre (98\% des enfants avaient des apports insuffisants), de légumineuses (97\%), de fruits (96\%), de viande et de volaille (95\%) et de lait et de produits laitiers (82\%).

Conclusion: L'état nutritionnel et l'insécurité alimentaire chez les enfants travailleurs au Pakistan sont comparables avec ceux de la population générale, ce qui souligne la gravité de la situation de ce pays en matière de sécurité alimentaire.

$$
\begin{aligned}
& \text { سوء التغذية وانعدام الأمن الغذائي في العمال الأطفال في السند، باكستان: دراسة مقطعية }
\end{aligned}
$$

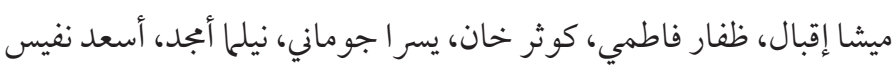

الخلفية: يشيع عمل الأطفال في البلدان المنخفضة والمتوسطة الدخل . وعلى الرغم من انتشار عمل الأطفال في باكستان على نطاق واسع، إلا أنه لا توجد بيانات بشأن صحة العمال الأطفال.

الأهداف: هدفت هذه الدراسة إلى تقييم الأمن الغذائي، والمدخول الغذائي، و الوضع التغذوي للعحال الأطفال الذين تتراوح أعمارهم بين 14 -5 عاماً ويعملون في السند السفلي، باكستان.

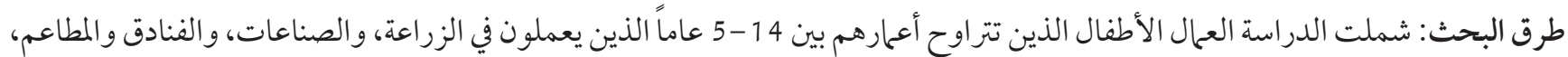

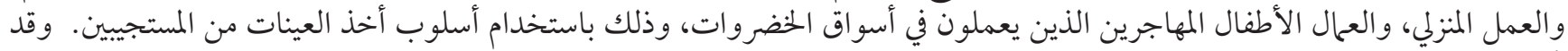

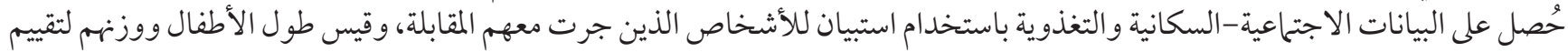

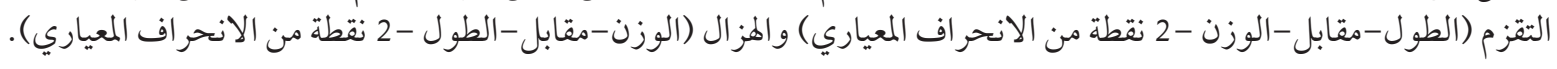

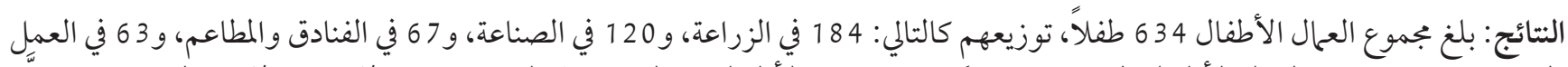

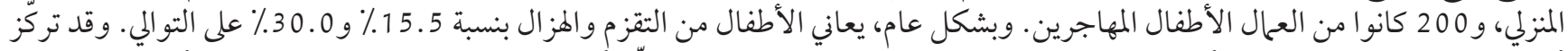

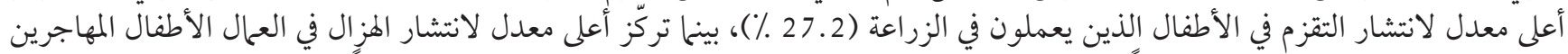

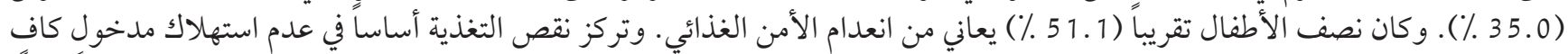

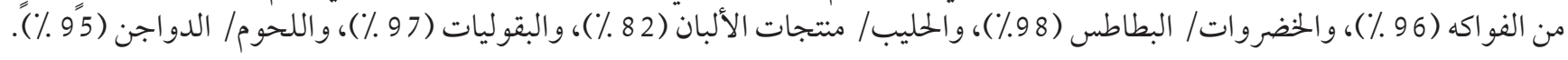
الاستنتاجات: يتقارب الوضع التغذوي و انعدام الأمن الغذائي للعحال الأطفال في باكستان مع السكان عمو ماً، مما يلقي الضوء على خطورة الوضع في البلد في ما يتعلق بالأمن الغذائي. 


\section{References}

1. Defining child labour. Geneva: International Labor Organization (http://www.ilo.org/ipec/facts/lang--en/index.htm, accessed 26 March 2018).

2. Global estimates of child labour: Results and trends, 2012-2016. Geneva: International Labour Organization; 2017 (https://www. ilo.org/wcmsp5/groups/public/@dgreports/@dcomm/documents/publication/wcms_575499.pdf, accessed 26 March 2018).

3. Briefing kit for Pakistan: Floods - Jul 2010. RekiefWeb; 30 Aug 2010 (http://ict4peace.pbworks.com/f/Pakistan_Floods_Jul_2010OCHA-88TEV6.pdf, accessed 29 March 2018).

4. Zulfiqar H. Ravages of rain stories of monsoon 2011; disaster in Sindh. Karachi: Health and Nutrition Development Society (HANDS); 2011.

5. Chris T. In wake of the floods, malnutrition threatens thousands of children in Pakistan. UNICEF, Pakistan; 21 November 2011 (https://www.unicef.org/emerg/pakistan_60617.html, accessed 30 March 2018).

6. Nengroo AH, Bhat GM. Why child labour? Evidences from homebased carpet weaving industry of Kashmir. Child Youth Serv Rev. 2017;79(8):50-6. https://doi.org/10.1016/j.childyouth.2017.05.032

7. Rad EH, Gholampoor H, Jaafaripooyan E. Child labor and the influencing factors: evidence from less developed provinces of Iran. Iran J Public Health. 2015;44(9):1244.

8. Putnick DL, Bornstein MH. Is child labor a barrier to school enrollment in low- and middle-income countries? Int J Educ Dev. 2015;41:112-20. https://doi.org/10.1016/j.ijedudev.2015.02.001

9. Mohammed ES, Ewis AA, Mahfouz EM. Child labor in a rural Egyptian community: an epidemiological study. Int J Public Health. 2014;59(4):637-44. https://doi.org/10.1007/s00038-014-0559-5

10. Younger DS. Health care in Brazil: implications for public health and epidemiology. Neurol Clin. 2016;34(4):1071-83. https://doi. org/10.1016/j.ncl.2016.06.002

11. Ibrahim A, Abdalla SM, Jafer M, Abdelgadir J, de Vries N. Child labor and health: a systematic literature review of the impacts of child labor on child's health in low-and middle-income countries. J Pub Health (Oxf). 2018;41(1):18-26. https://doi.org/10.1093/ pubmed/fdyo18

12. Tiwari RR, Saha A. Morbidity profile of child labor at gem polishing units of Jaipur, India. Int J Occup Environ Med. 2014;5(3):125-9.

13. Population Censes 2017. Pakistan: Pakistan Bureau of Statistics, Government of Pakistan; 2017 (http://www.pbs.gov.pk/content/ population-census, accessed 30 March 2018).

14. Summary results of child labour survey in Pakistan. Islamabad: Federal Bureau of Statistics, Statistics Division Ministry of Labour, Manpower and Overseas Pakistanis, International Labour Organization and International Programme on the Elimination of Child Labour; 1996 (https://www.ilo.org/wcmsp5/groups/public/---asia/---ro-bangkok/---sro-new_delhi/documents/publication/wcms_436435.pdf, accessed 30 March 2018).

15. Child labour increases in Pakistan while numbers drop internationally. Dawn 16 January 2016 (https://www.dawn.com/ news/1233219, accessed 25 February 2020).

16. Child in hazardous work: what we know, what we need to know. Geneva: International Labour Organization; 2011 (http://www. ilo.org/wcmsp5/groups/public/@dgreports/@dcomm/@publ/documents/publication/wcms_155428.pdf, accessed 19 April 2018).

17. Promoting jobs, protecting people. Ratifications for Pakistan. Geneva: International Labour Organization (http://www.ilo.org/ dyn/normlex/en/f?p=NORMLEXPUB:11200:0::NO::P11200_COUNTRY_ID:103166, accessed 19 April 2018).

18. Rahman MN, Mistry SK, Hossain MI. Nutritional status of child labourers in Dhaka city of Bangladesh: findings from a cross sectional study. Bangladesh J Child Health. 2014;38(3):130-6. https://doi.org/10.3329/bjch.v38i3.22821

19. Magnani R, Sabin K, Saidel T, Heckathorn D. Review of sampling hard-to-reach and hidden populations for HIV surveillance. AIDS. 2005;19(Suppl 2):S67-72. https://doi.org/10.1097/01.aids.0000172879.20628.e1

20. National Health Interview Survey, 2016. Atlanta, GA: Centers for Disease Control and Prevention; 2016 (https://nhis.ipums.org/ nhis/resources/surveys_pdf/survey_form_ih2016_fam.pdf, accessed 26 March 2018).

21. Napoli M, De Muro P, Mazziotta M. Towards a food insecurity multidimensional index. Rome: Roma Tre University/Human Development and Food Security; 2011 (http://www.fao.org/fileadmin/templates/ERP/uni/FIMI.pdf, accessed 9 September 2018).

22. Malaysian dietary guidelines. Kuala Lumpur: Ministry of Health Malaysia; 2010 (http://dg.cnsoc.org/upload/affix/20140818104029708.pdf, accessed 3 September 2018).

23. USAID. Key findings of the national nutrition survey of 2011. Islamabad: Research and Development Solutions; 2013 (http:// www.resdev.org/files/policy_brief/41/Policy\%20Brief\%2041\%20-\%20Nutritional\%20Status.pdf, accessed 5 May 2018).

24. Pakistan Food Security Bulletin, Issue 3. Pakistan: World Food Programme; Aug 2015 (https://reliefweb.int/sites/reliefweb.int/ files/resources/wfp278089.pdf, accessed 4 February 2020).

25. Pakistan Demographic and Health Survey 2017-18. Islamabad and Rockville (MD): National Institute of Population Studies and ICF; 2019.

26. Sindh multiple indicator cluster survey 2014. Final report. Karachi: Sindh Bureau of Statistics and UNICEF; 2015. 
27. Ali M, Shahab S, Ushijima H, de Muynck A. Street children in Pakistan: a situational analysis of social conditions and nutritional status. Soc Sci Med. 2004;59(8):1707-17. https://doi.org/10.1016/j.socscimed.2004.01.031

28. Cardoso MD, Casiño JM. Child labor, nutritional status, and academic performance of Filipino children. US-China Educ Rev. 2015;5(9):604-12. https://doi.org/10.17265/2161-6248/2015.09.007

29. Pasdar Y, Darbandi M, Nachvak SM. Nutritional status of working children as a neglected group in Kermanshah. J Com Health Research. 2014;3(2):124-31.

30. Penrod J, Preston DB, Cain RE, Starks MT. A discussion of chain referral as a method of sampling hard-to-reach populations. J Transcult Nurs. 2003;14(2):100-7. https://doi.org/10.1177\%2F1043659602250614 